\title{
PENGARUH EKSTRAK RIMPANG KENCUR (Kaempferia galanga L.) TERHADAP TINGKAT KESEMBUHAN BENIH IKAN LELE DUMBO (Clarias sp) YANG TERINFEKSI Saprolegnia sp.
}

\section{EFFECT OF RHIZOME EXTRACT (Kaempferia galanga L.) FOR THE CURE RATE OF CATFISH FRY (Clarias sp) INFECTED by Saprolegnia sp.}

\author{
Nadia Fierias Fathma Riza, Hari Suprapto dan Rahayu Kusdarwati \\ Fakultas Perikanan dan Kelautan Universitas Airlangga \\ Kampus C Mulyorejo - Surabaya, 60115 Telp. 031-5911451
}

\begin{abstract}
Saprolegnia sp. is a fungus that causes the disease Saprolegniasis on eggs and fresh water fish such as catfish (Clarias sp.). Treatment of Saprolegniasis have done using chemical drugs such as malachite green, formalin, sodium chloride and asetic acid. However, the use of chemical drugs is bad for the environment and biota.

The purpose of this study is to determined the antifungal activity from rhizome extract (Kaempferia galanga L.) for the cure rate of catfish fry (Clarias sp) infected by Saprolegnia sp. The research was conducted on June 2013 at Fisheries and Marine Faculty of Airlangga University. The method used in this study is experimental method using Kruskall Wallis followed by Two Sample Independent test design with 5 treatments and four repetitions.

Results showed that the extract of Kaempferia galanga L. has antifungal activity to recovery infected catfish fry. The optimal concentration from this research is $64 \%$. The existence of antifungal activity of Kaempferia galanga L. extracts to Saprolegnia sp. showed that Kaempferia galanga L. extract consists some compounds as fungistatic and fungicidal such as flavonoid, saponin, phenolic and essential oil compounds.
\end{abstract}

Keywords : Rhizome Extract, Saprolegnia sp., Cure Rate

\section{Pendahuluan}

Perkembangan budidaya ikan akhirakhir ini masih terkendala dengan serangan penyakit ikan yang menjadi salah satu faktor pembatas. Salah satu penyakit yang biasa menyerang ikan lele adalah penyakit saprolegniasis atau penyakit white cotton growth yang disebabkan oleh jamur Saprolegnia sp (Muklishoh, 2008).

Menurut Data statistik dari Departemen Kelautan dan Perikanan Direktorat Jendral Budidaya (2012), nilai produksi ikan lele di Jawa Timur pada tahun 2008 sebesar 274.542 ton dan tahun 2010 naik sebesar 407.555 ton. Dari tahun 2007-2011 permintaan lele sebesar 59,09\% dan tahun 2010-2012 meningkat dengan nilai permintaan sebesar $67,74 \%$ sekitar 900.000 ton.

Penyakit mikotik pada ikan lele akan muncul setelah dua minggu lele ditebar. Ikan lele mudah terserang penyakit karena lele merupakakan ikan yang tidak bersisik, sehingga kulitnya tidak dapat terlindungi apabila terkena gangguan lingkungan (Dardiani dan Intan, 2010).

Upaya pencegahan dan pengobatan yang lazim dilakukan pada ikan-ikan yang terkena penyakit mikotik adalah menggunakan bahan kimia seperti malachite green, formalin, hidrogen peroxida, dan sebagainya. Penggunaan bahan kimia cenderung tidak ramah lingkungan dan ada yang bersifat karsinogenik (Fakhrizal dkk., 2013).

Fitofarmaka sudah sangat dikenal terutama untuk pengobatan manusia, namun belum dimanfaatkan dalam budidaya ikan. Beberapa jenis fitofarmaka yang dapat dicobakan untuk pengobatan penyakit ikan karena merupakan bahan alami yang mudah hancur sehingga aman dan ramah lingkungan adalah penggunaan rimpang kencur (Kaempferia galanga L.) yang mengandung flavonoid, saponin, senyawa polifenol dan minyak atsiri (Gholib, 2009).

Tanaman tersebut memiliki potensi untuk menghambat dan membunuh pertumbuhan jamur sehingga perlu dilakukan percobaan pengaruh ekstrak rimpang kencur sebagai bahan pengobatan alternatif untuk mengatasi infeksi pada benih ikan lele yang disebabkan oleh jamur Saprolegnia sp.

Tujuan dalam penelitian ini adalah untuk mengetahui potensi ekstrak rimpang kencur (Kaempferia galanga L.) untuk 
menyembuhkan benih ikan lele (Clarias sp) yang terinfeksi Saprolegnia sp. dan untuk mengetahui dosis optimal dari ekstrak rimpang kencur (Kaempferia galanga L.) untuk mengatasi infeksi Saprolegnia sp pada benih ikan lele (Clarias sp). Manfaat yang dapat diperoleh dari penelitian ini diharapkan dapat memberikan informasi ilmiah kepada masyarakat bahwa serangan jamur Saprolegnia sp. dapat ditangani dengan pemberian ekstrak rimpang kencur dan dapat digunakan sebagai dasar pengembangan penelitian selanjutnya dan dapat berguna dalam mendukung perkembangan perikanan

\section{Materi dan Metode}

Waktu dan Tempat

Penelitian ini dilakukan di Fakultas Perikanan dan Kelautan, Universitas Airlangga, Surabaya. Penelitian telah dilaksanakan selama satu bulan. Penelitian ini dilaksanakan pada bulan Juni 2013 dan selesai pada bulan September 2013.

\section{Sterilisasi Alat dan Media}

Penyediaan wadah uji sebelum digunakan, wadah uji dibersihkan dan didesinfeksi terlebih dahulu dengan chlorine selama 30 menit, kemudian dibilas dengan air bersih dan dikeringkan (Rahmaningsih, 2012). Upaya untuk mencegah adanya kontaminasi pada alat dan media, cawan Petri dan media yang digunakan dimasukkan dalam autoklaf bertekanan $1 \mathrm{~atm}$ pada suhu $121{ }^{0} \mathrm{C}$ selama 15 menit, serta meja dan alat yang digunakan dibersihkan dengan alkohol $70 \%$.

\section{Kultur dan Identifikasi Saprolegnia sp}

Proses harus dilakukan dalam kondisi aseptis untuk meminimalkan terjadinya kontaminasi oleh bakteri. Sampel yang didapat dari biakan murni kemudian ditanam pada media SDA dan penanamannya dilakukan di belakang api bunsen untuk mencegah kontaminasi. Media diberi label pada bungkusnya dan diinkubasi pada suhu $27-28^{\circ} \mathrm{C}$ selama 4-5 hari. Setelah diinkubasi, koloni jamur yang tumbuh dapat diidentifikasi teknik selotip.

Metode selotip merupakan metode identifikasi yang paling sederhana. Selotip yang telah berisi jamur ditempelkan pada object glass yang sudah ditetesi dengan lactophenol blue lalu diamati di bawah mikroskop dengan pembesaran 100x dan 400x (Balai Karantina Ikan, 2011).

\section{Pembuatan Larutan Zoospora}

Pembuatan larutan zoospora dilakukan untuk menginfeksi jamur ke suatu organisme air. Bagian jamur yang berperan sebagai penginfeksi adalah zoospore yang dihasilkan dari sporangium pada media air. Infeksi buatan dilakukan dengan cara perendaman spora Saprolegnia sp. yang berasal dari hasil kultur media SDA. Sebelum dilakukan perendaman terlebih dahulu dilakukan penghitungan spora dengan menggunakan haemacytometer. Kepadatan spora minimal yang akan direndam adalah sebanyak $2 \times 10^{5}$ spora/ml (Hatai and Hoshiai, 1993).

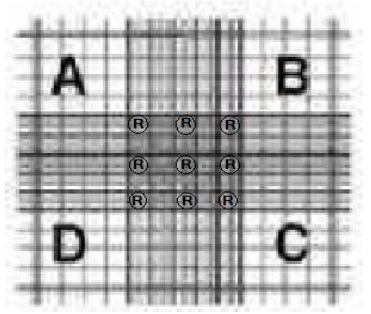

Gambar 1. Penampang Haemacytometer

Keterangan : A, B, C, dan D = kotak besar, sedangkan sel dihitung pada 9 kotak sedang (R) pada haemacytometer.

Diketahui : volume kotak sedang

$=(0,2 \times 0,2 \times 0,1) \mathrm{mm}^{3}$

$=0,000004 \mathrm{~cm}^{3}=4 \times 10^{-6} \mathrm{ml}$

$$
\text { - Jumlah spora = }=426
$$

$\left(\frac{\text { sel }}{\mathrm{ml}}\right)=$ rataan sel terhitung $\mathrm{x} \frac{1}{4 \times 10^{-6}} \mathrm{x}$ pengencer $=\frac{426}{9} \times \frac{1}{4} \times 10^{6} \times 10^{-1}$

$=47,33 \times 0,25 \times 10^{5}$

$=1,18 \times 10^{6} \mathrm{sel} / \mathrm{ml}$

Perhitungan zoospora dalam penelitian ini dilakukan dengan cara meneteskan $1 \mathrm{ml}$ suspense fungi ke dalam haemacytometer yang telah ditutup cover glass melalui bagiannya yang berlekuk hingga memenuhi seluruh bagian yang berskala. Penghitungan dilakukan di bawah mikroskop dengan perbesaran 400 kali di 9 kotak sedang pada haemacytometer.

Pembuatan Salep Ekstrak Rimpang Kencur
Salep dibuat dengan cara mencampurkan ekstrak rimpang kencur dengan bahan pembawa berupa vaselin. Salep yang akan dibuat sebanyak 10 gram, sehingga dosis ekstrak yang ditentukan akan dicampur dengan vaselin dan dihomogenisasi dengan menggunakan mortar. Salep yang telah jadi 
dapat disimpan dalam tabung dan diberi label. Cara membuat salep adalah sebagai berikut :
$16 \%: 1,6$ gram ekstrak $+8,4$ gram vaselin
$32 \%: 3,2$ gram ekstrak $+6,8$ gram vaselin
$64 \%: 6,4$ gram ekstrak $+3,6$ gram vaselin

Tahapan Perlakuan

Menginfeksi Benih Ikan Lele Dengan Jamur Saprolegnia sp.

Benih ikan lele dilukai terlebih dahulu pada bagian punggung dengan panjang luka sekitar $3 \mathrm{~mm}$ dengan menggunakan pinset. Ikan dimasukkan ke dalam akuarium yang berisi air empat liter yang telah terkontaminasi jamur Saprolegnia sp. sebanyak 1,18 × $10^{6} \mathrm{sel} / \mathrm{ml}$ selama kurang lebih tiga hari.

Metode Pengobatan

Metode pengobatan yang digunakan adalah metode pengolesan. Proses pengolesan diawali dengan menarik jamur Saprolegnia sp pada bagian tubuh ikan yang terkena jamur dengan menggunakan gunting atau pinset, kemudian bagian tersebut diolesi dengan salep ekstrak rimpang kencur dengan bantuan cutton bud sebanyak konsentrasi yang ditentukan. Pengolesan dilakukan sehari setelah ikan diinfeksi. Ikan yang sudah diberi perlakuan dimasukkan kembali ke dalam akuarium pengobatan dan pemeliharaan yang sudah diisi air bersih.

Metode pengobatan diulang setiap satu kali sehari sampai ikan terlihat normal. Ikan yang telah diobati selama tujuh hari tersebut kemudian di scrapping pada bagian kulit untuk di reisolasi untuk mengetahui jumlah koloni jamur pada tubuh ikan. Selama kegiatan ikan diberi pakan berupa pelet dengan frekuensi pemberian pakan tiga kali sebanyak 3\% berat badan ikan rata-rata sehari yaitu sekitar dua gram pada pagi hari sekitar jam 08.00 WIB, siang jam 12.00 WIB dan sore hari sekitar jam 16.00 WIB.

Analisis Data

Data skoring yang berasal dari hasil reisolasi ikan pada penelitian ini kemudian diuji dengan Kruskal Wallis dengan taraf kepercayaan $95 \%$. Analisis statistika dilakukan dengan menggunakan SPSS versi 19.0 for Windows dan dilanjutkan dengan analisis dua sampel independen untuk melihat perbandingannya.
Tabel 1. Skoring tingkat kesembuhan

\begin{tabular}{|c|c|c|}
\hline $\begin{array}{c}\text { Jumlah } \\
\text { Koloni }\end{array}$ & $\begin{array}{c}\text { Tingkat } \\
\text { Kesembuhan }\end{array}$ & Skor \\
\hline$>30$ & Sakit & 1 \\
$20-30$ & Sedang & 2 \\
$10-20$ & Ringan & 3 \\
$<10$ & Sembuh & 4 \\
\hline
\end{tabular}

\section{Hasil dan Pembahasan}

Proses identifikasi dilakukan untuk memastikan kebenaran terhadap isolat jamur yang didapatkan dari Jurusan Biologi Fakultas Sains dan Teknologi Universitas Airlangga bahwa jamur tersebut adalah Saprolegnia sp. Isolat jamur diidentifikasi secara morfologi mikroskopi dan makroskopi (Purwantisari dkk., 2009).

Pengamatan morfologi secara makroskopis dapat dilihat dari bentuk dan warna koloni jamur. Koloni Saprolegnia sp. berwarna putih buram dan berbentuk seperti kapas. Pengamatan mikroskopis menunjukkan bahwa Saprolegnia sp. memiliki hifa yang lebih besar yaitu berkisar $26-40 \mu \mathrm{m}$. Ujung hifa membulat dengan sporulasi tanpa membentuk kista di mulut sporangium, hal ini sesuai dengan yang dikutip oleh Nuryati dkk., (2008). Pengamatan secara makroskopis dan mikroskopis dapat dilihat pada Gambar 2.

Tujuan dilakukannya pengamatan reisolasi adalah untuk mengetahui tingkat kesembuhan benih ikan lele yang terinfeksi oleh Saprolegnia sp. dan diobati dengan menggunakan salep ekstrak rimpang kencur.

Tahapan awal dari proses reisolasi adalah dengan melakukan scrapping pada seluruh permukaan tubuh ikan dan kemudian ditanamkan pada media Saboroud Dextrose Agar (SDA) dan diinkubasi selama tiga hari dengan suhu $25-28^{\circ} \mathrm{C}$. Hasil reisolasi dapat dilihat pada Gambar 3.

Hasil penghitungan jumlah koloni kemudian dianalisis dengan menggunakan uji statistik Kruskall Wallis agar diketahui skoring dari tiap-tiap perlakuan. Skoring digunakan untuk menentukan tingkat kesembuhan benih ikan yang terinfeksi jamur. Data analisis statistik dapat dilihat pada Tabel 3.

Survival rate (SR) atau biasa dikenal dengan sintasan dalam perikanan budidaya merupakan indeks kelulushidupan suatu jenis ikan dari mulai awal ikan ditebar hingga ikan dipanen. Survival rate merupakan salah satu faktor penentu keberhasilan suatu budidaya. Survival rate ditulis dalam bentuk presentase mulai dari $0-100 \%$. 


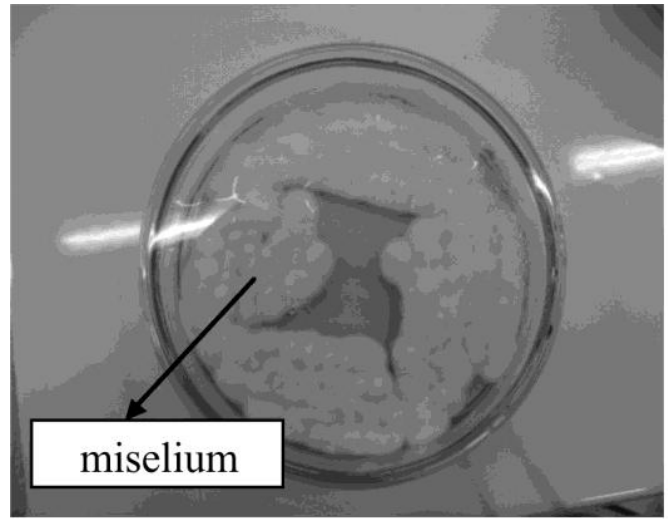

(a)

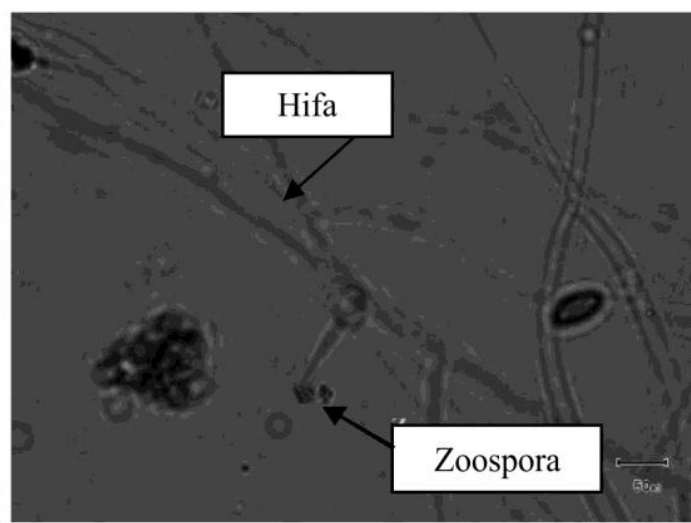

(b)

Gambar 2. (a). Koloni Saprolegnia sp. pada media SDA

(b) Saprolegnia sp. secara mikroskopis

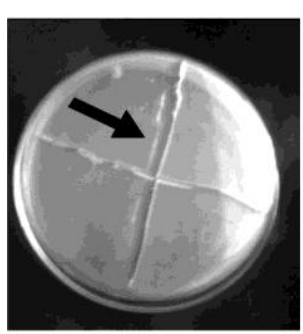

(a)

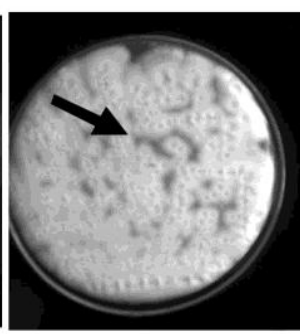

(b)

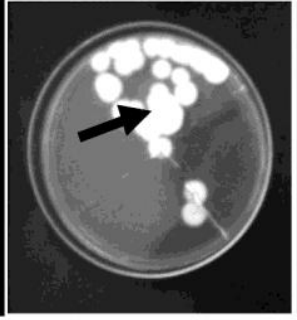

(c)

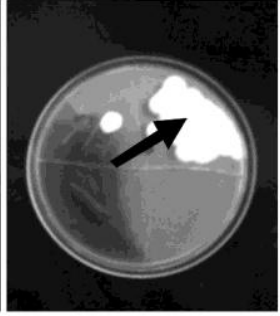

(d)

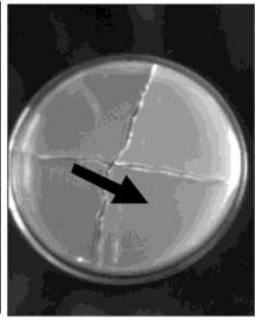

(e)

Gambar 3: (a). Hasil reisolasi ikan pada perlakuan A (kontrol +)

(b). Hasil reisolasi ikan pada perlakuan B (kontrol -)

(c). Hasil reisolasi ikan pada perlakuan C (dosis 16\%)

(d). Hasil reisolasi ikan pada perlakuan D (dosis 32\%)

(e). Hasil reisolasi ikan pada perlakuan E (dosis 64\%)

Tabel 2. Data Skoring Analisis Statistik

\begin{tabular}{|l|c|c|}
\hline Perlakuan & Skor & Mean Rank \\
\hline A (Kontrol +) & 4 & 15,50 \\
B (Kontrol -) & 1 & 2,75 \\
C (16\%) & 2 & 7,63 \\
D (32\%) & 3 & 11,13 \\
E (64\%) & 4 & 15,50 \\
\hline
\end{tabular}

Tabel 3. Hasil kelulushidupan benih ikan lele selama tujuh hari

\begin{tabular}{|l|l|l|l|l|}
\hline Perlakuan & $\begin{array}{l}\text { Jumlah ikan } \\
\text { awal }\end{array}$ & $\begin{array}{l}\text { Jumlah ikan } \\
\text { akhir }\end{array}$ & Kematian & $\begin{array}{l}\text { Rata-rata } \\
\text { kelulushidupan (\%) }\end{array}$ \\
\hline A (Kontrol +) & 8 & 8 & 0 & 100 \\
B (Kontrol -) & 8 & 7 & 1 & 87,5 \\
C (16\%) & 8 & 6 & 2 & 75 \\
D (32\%) & 8 & 8 & 0 & 100 \\
E (64\%) & 8 & 7 & 1 & 87,5 \\
\hline
\end{tabular}


Tabel 4. Hasil rata-rata pengamatan nilai kualitas air selama tujuh hari.

\begin{tabular}{|l|c|c|c|}
\hline \multirow{2}{*}{ Perlakuan } & \multicolumn{3}{|c|}{ Kisaran parameter kualitas air yang diamati selama tujuh hari } \\
\cline { 2 - 4 } & $\mathrm{pH}$ & $\mathrm{DO}(\mathrm{mg} / \mathrm{L})$ & Suhu $\left({ }^{\circ} \mathrm{C}\right)$ \\
\hline A (Kontrol +) & $7-8$ & 4 & $27-28$ \\
B (Kontrol -) & $6-8$ & $4-5$ & $27-28$ \\
C (16\%) & $6-8$ & $4-5$ & $27-28$ \\
D (32\%) & $7-8$ & 4 & $27-28$ \\
E $(64 \%)$ & $7-8$ & $4-5$ & 28 \\
\hline
\end{tabular}

Penggunaan ekstrak rimpang kencur (Kaempferia galanga L.) terhadap tingkat kesembuhan benih ikan lele dumbo (Clarias sp.) yang terinfeksi Saprolegnia sp. dinilai berpotensi sebagai obat untuk mencegah dan menanggulangi serangan penyakit jamur karena pada penelitian ini telah didapatkan dosis optimal dari salep ekstrak rimpang kencur (Kaempferia galanga L.) sebesar 64\% .

Hasil uji statistik menunjukkan bahwa tidak terdapat perbedaan antara perlakuan ekstrak rimpang kencur konsentrasi 64\% dengan kontrol positif. Jika konsentrasi ekstrak lebih kecil dari $64 \%$ maka ekstrak tidak mampu untuk membunuh Saprolegnia sp. Semakin besar konsentrasi ekstrak rimpang kencur maka, semakin besar pula daya hambat ekstrak tersebut terhadap pertumbuhan Saprolegnia sp. Hal ini sesuai dengan Kosenda (2009) yang menyatakan bahwa semakin tinggi konsentrasi obat maka kematian atau penghambatan pertumbuhan jamur akan semakin besar.

Senyawa aktif yang bersifat antifungi berupa flavonoid, saponin, senyawa polifenol dan minyak atsiri (Gholib, 2009). Menurut Barus (2009) minyak atsiri pada rimpang kencur sebagian besar banyak mengandung senyawa etil p- metoksisinamat (EPMS) yang umumnya dapat larut dalam pelarut etanol, etil asetat, methanol dan heksan.

Menurut Waji dan Andis (2009) flavonoid merupakan senyawa metabolit sekunder yang terdapat pada tanaman. Fungsi metabolit sekunder adalah untuk mempertahankan diri dari kondisi lingkungan yang kurang menguntungkan, misalnya untuk mengatasi hama dan penyakit, menarik polinator, dan sebagai molekul sinyal. Metabolit sekunder digunakan organisme untuk berinteraksi dengan lingkungannya.. Salah satu golongan flavonoid adalah kalkon. Kalkon sebagai senyawa yang bersifat fungistatik dan fungisida yang terdapat pada tumbuhan Kaempferia dari golongan Zingiberaceae. Selain itu flavonoid mempunyai senyawa genestein berfungsi menghambat pembelahan atau proliferasi sel jamur.
Pengaruh senyawa fenol sebagai antifungal adalah dengan mendenaturasi ikatan protein pada membran sel sehingga membran sel lisis dan memungkinkan fenol menembus ke dalam inti sel yang menyebabkan jamur tidak berkembang (Sulistyawati dan Mulyati, 2009).

Menurut Agusta (2006) terdapat dua tahap mekanisme obat anti jamur yaitu dengan menghambat reaksi demetilase eburikol menjadi 4,4 demetilfekosterol dan penghambatan reaksi C 24 alkilase yaitu proses penghambatan alkilase lanosterol untuk menghalangi terbentuknya eburikol. Menurut Brennan and Leyden (1997) hal ini mengakibatkan dinding sel menjadi permeabel dan struktur sel jamur hancur karena senyawa anti jamur menghambat biosintesis ergosterol yang merupakan sterol utama untuk mempertahankan integritas membran sel jamur.

Kisaran rata-rata tingkat kelangsungan hidup benih ikan lele dalam penelitian ini adalah $75-100 \%$, hal ini hampir mendekati pendapat Rusmansyah (2012) yang menyatakan bahwa tingkat kelulushidupan benih ikan lele berkisar antara 80-90\%. Mortalitas ikan terbanyak terdapat pada perlakuan C (16\%). Kematian ikan yang terjadi dapat disebabkan oleh beberapa faktor seperti kondisi lingkungan dan sistem kekebalan tubuh. Perlakuan dengan dosis $16 \%$ menunjukkan bahwa kondisi lingkungan berada pada batas normal sehingga kemungkinan kematian ikan disebabkan oleh rendahnya sistem kekebalan tubuh ikan dan respon terhadap obat yang diberikan.

Pada perlakuan A (kontrol +) dan perlakuan E (dosis 64\%) tidak terdapat mortalitas atau dapat dikatakan tingkat kelulushidupan ikan pada perlakuan ini adalah $100 \%$, hal ini dikarenakan ikan terinfeksi telah diobati dengan menggunakan salep ekstrak rimpang kencur sehingga kematian akibat penyakit dapat terminimalisir.

Parameter kualitas air dalam penelitian ini diantaranya suhu, $\mathrm{pH}$ dan oksigen terlarut. Suhu air media pemeliharaan berkisar $27-28^{\circ} \mathrm{C}$, oksigen terlarut (DO) berkisar $4-5 \mathrm{mg} / \mathrm{l}$ dan $\mathrm{pH}$ berkisar 7-8, hal ini sesuai dengan pendapat 
Menegristek (2000) yang menyatakan bahwa ikan lele dapat hidup pada suhu $20^{\circ} \mathrm{C}$, dengan suhu optimal antara $25-28^{\circ} \mathrm{C}$. Kualitas air memiliki peranan penting dalam kegiatan budidaya. Ketidakseimbangan kondisi air dapat menimbulkan beberapa masalah seperti penyakit yang dapat mengakibatkan kematian bagi ikan budidaya. Keadaan kualitas air yang berada dibawa ambang normal dapat memicu tumbuhnya organisme patogen salah satunya jamur. Oleh karena itu salah satu upaya pencegahan munculnya organisme patogen penyebab penyakit adalah dengan menjaga keseimbangan air media budidaya ikan.

\section{Kesimpulan}

Berdasarkan hasil analisis dan pembahasan dalam penelitian ini, dapat disimpulkan sebagai berikut: ekstrak rimpang kencur (Kaempferia galanga L.) dalam bentuk sediaan salep dapat digunakan untuk mengatasi infeksi jamur Saprolegnia sp pada benih ikan lele dumbo dengan dosis optimal salep ekstrak rimpang kencur (Kaempferia galanga L) dalam penentuan tingkat sembuh benih ikan lele yang terinfeksi Saprolegnia sp adalah 64\% (6,4 gram ekstrak rimpang kencur (Kaempferia galanga L) + 3,6 gram vaselin).

Berdasarkan hasil penelitian yang dilakukan, penulis menyarankan untuk lebih memperhatikan kualitas air dan kondisi lingkungan budidaya ikan guna mencegah kematian pada ikan. Penelitian lebih lanjut tentang histopatologi ikan yang diberi pengobatan menggunakan salep ini juga dibutuhkan.

\section{Daftar Pustaka}

Agusta, A. 2006. Diversitas Jalur Biosintesis Senyawa Terpena Pada Makhluk Hidup Sebagai Target Obat Antiinfektif. Laboratorium Fitokimia Bidang Botani. Pusat Penelitian Biologi. Lembaga Ilmu Pengetahuan Indonesia. Bogor. Berita Biologi 8(2) : 141-150.

Balai Karantina Ikan. 2011. Teknik Identifikasi Jamur Metode Selotip. Balai Karantina Ikan Kelas II. Tanjung Emas. Semarang.

Barus, R. 2009. Amidasi Etil P-Metoksisinamat yang diisolasi Dari Kencur (Kaempferia galangal Linn). Tesis. Universitas Sumatera Utara. Medan. Hal. 23

Brennan B. and Leyden JJ. 1997. Overview of Topical Theraphy for Common Supperficial Fungal Infection and The
Role of New Topical Agents. Journal of American Academy of Dermatology Part 1. Volume $36: 2$.

Dardiani dan Intan. 2010. Mata Diklat 5 : Manajemen Pemeliharaan Benih. Departemen Pendidikan Nasional. Pusat Pengembangan dan Pemberdayaan Pendidik dan Tenaga Kependidikan Pertanian.

Departemen Kelautan dan Perikanan Direktorat Jendral Budidaya, 2012. Statistik Kelautan dan Perikanan 2012. Jakarta. hal 95-119.

Fakhrizal, A.N, Eka,R dan Tsaqif, I. 2013. Pengaruh Ekstrak Bawang Putih Dengan Dosis Yang Berbeda Terhadap Mortalitas Kutu Ikan (Argulus Sp.) Yang Menginfeksi Ikan Mas Koki (Carassius auratus Linn). Jurusan Budidaya Perairan. Universitas Lambung Mangkurat. Banjarbaru. 6hal.

Gholib, D. 2009. Daya Hambat Ekstrak Kencur (Kaempferia galanga L.) terhadap Trichophyton mentagrophytes dan Cryptococcus neoformans. Balai Besar Penelitian Veteriner. 20(1) : 59-67.

Hatai K. \& Hoshiai G.I. (1993) Characteristics of two Saprolegnia species isolated from coho salmon with saprolegniosis. Journal of Aquatic Animal Health 5, 115-118.

Kosenda, L. 2009. Penampisan Senyawa Bioaktif dari Daun Jambu Biji (Psidium guajava L.) sebagai Anticandidiasis dan Profil Kromatografi Lapis Tipisnya. Skripsi. Fakultas Kedokteran dan Ilmu-Ilmu Kesehatan. Purwokerto. 167hal.

Menegristek. 2000. Tekhnologi Tepat Guna Budidaya Ikan Lele (Clarias sp.). Kantor Deputi Menegristek Bidang Pendayagunaan dan Pemasyarakatan IPTEK. Jakarta. 17hal.

Musklishoh, S.S. 2008. Karakterisasi Morfologi Dan Patogenisitas Jamur Penyebab Saprolegniasis Pada Jaringan Tubuh Ikan Gurami(Osphronemus goramy Lac.) Dan Ikan Lele (Clarias batrachus L.). Tesis. Fakultas Biologi. Universitas Gajah Mada. Yogyakarta. hal 1-7.

Nuryati, S., F.B.P. Sari., dan Taukhid, 2009, identifikasi dan uji postulat Koch cendawan penyebab penyakit pada ikan gurame. Proram studi budidaya perairan. Fakultas perikanan dan ilmu kelautan. Institute pertanian bogor. Bogor. Hal:21-27. 
Purwantisari, 2009. Isolasi dan Identifikasi Janur Indigenous Rhizosfer Tanaman Kenteng Organik di Desa Pakis Magelang.FMIPA UNDIP. Vol-11. No.2.

Rahmaningsih, S. 2012. Pengaruh Ekstrak Sidawayah Dengan Konsentrasi Yang Berbeda Untuk Mengatasi Infeksi Bakteri Aeromonas hydrophilla Pada Ikan Nila (Oreochromis niloticus). Jurnal Aquasains Vol.1 Fakultas Pertanian Universitas Lampung. Lampung.
Sulistyawati, D. dan Mulyati, S. 2009. Uji Aktivitas Antijamur Infusa Daun Jambu Mete (Ana ca rdium o ccidentale, L.) terhadap Candida albicans. Biomedika. 2(1): 47-51.

Waji R.A. dan Andi S. 2009. Makalah Kimia Organik Bahan Alam Flavonoid (Quercetin). Program S2 Kimia Fakultas Matematika Dan Ilmu Pengetahuan Alam. Universitas Hassanudin. 4hal. 